Vol. 1, No. 1 Mei 2021 Hal. 5-11

Jurnal IImiah Teknik Informatika, Elektronika dan Kontrol (Scientific Journal of Informatics, Electronics and Control Engineering)

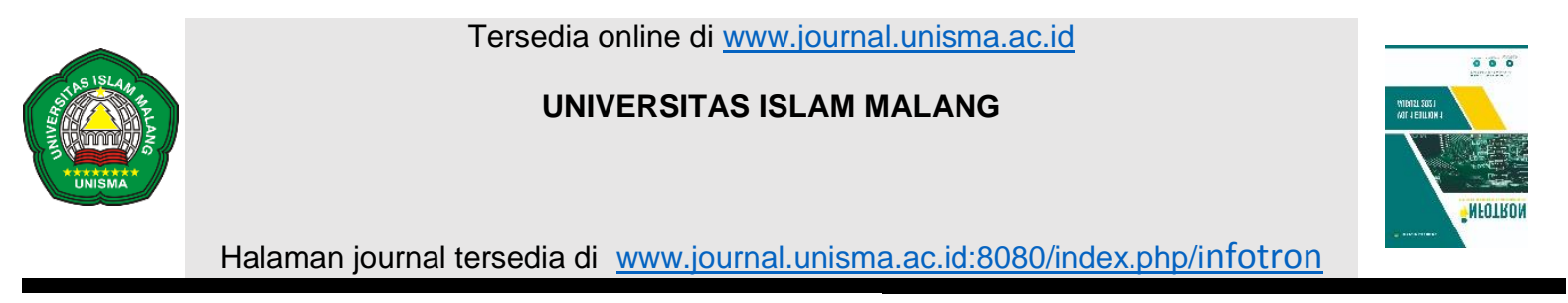

\title{
PEMANFAATAN TEKNOLOGI ANDROID SEBAGAI SARANA PEMBELAJARAN SENI MUSIK AL-BANJARI MENGGUNAKAN APLIKASI VIRTUAL AL-BANJARI
}

\author{
Ach. Nailur Rizqi', M. Syarif Hidayatulloh ${ }^{2}$, Moch. Hatta $^{3}$ \\ a1,2Teknik Informatika, Fakultas Teknik \\ ${ }^{3}$ Teknik Komputer, Fakultas Teknik \\ Universitas Maarif Hasyim Latif, Sidoarjo \\ Jl. Raya Ngelom Megare No.30, Ngelom, Taman, Sidoarjo, Jawa Timur 61257, (031) 7885205 \\ e-mail: ${ }^{1}$ ach-nailur-rizqi@student.umaha.ac.id, ${ }^{2}$ syarif_hidayatulloh@dosen.umaha.ac.id,3moch.hatta@dosen.umaha.ac.id
}

\section{INFORMASI \\ ARTIKEL}

\section{Sejarah artikel:}

Received 6 Mei 2021

Accepted 3 Juni 2021

Kata kunci: Seni musik, Albanjari, Android.

\section{A B S T R A K}

Seni musik al-banjari merupakan salah satu seni musik tradisional asli Indonesia, yang dikemas sebaik mungkin yang didalam musik tersebut ada sholawat didalamnya di tambah alunan suara bas, terbang, dan Keplak yang menjadi satu sehingga terbentuklah suatu seni musik yang saat ini dikenal dengan istilah Albanjari. Perkembangan musik al-banjari, sudah banyak grub-grub banjari bermunculan, karena mengingat al-banjari sangat menghibur, di sisi lain, mereka juga bersholawat kepada Nabi Muhammad SAW. Selain dengan bertambah banyaknya grub banjari yang bermunculan, banyak juga festival sholawat albanjari pada momen-momen tertentu, seperti yang pernah di selenggarakan oleh UKM UKKI UMAHA yang sudah rutin tiap tahun mengadakan festival tersebut. Karena harga alat musik al-banjari yang tergolong agak mahal untuk pelajar, penulis memiliki sebuah gagasan untuk menciptakan sebuah aplikasi "Alat Musik Berbasis Android", aplikasi tersebut bertujuan untuk membuat suatu alat pembelajaran memainkan alat musik tradisional al-banjari secara mobile berbasis android, selain itu juga memberikan pengetahuan tentang macam macam alat musik al-banjari, dan cara memainkan alat musik terbsebut. Dengan diciptakannya aplikasi ini memungkinkan pengguna untuk berinteraksi secara langsung dalam proses bermain musik al-banjari sesuai dengan mekasnisme alat musik yang sesungguhnya.

(C) 2021 INFOTRON: Jurnal IImiah Teknik Informatika, Elektronika dan Kontrol (Scientific Journal of Informatics, Electronics and Control Engineering). Copyrights. All rights reserved.

\section{Pendahuluan [Kepala Bagian]}

Negara Indonesia adalah negara yag beraneka ragam budaya dan juga kesenian, salah satunya yaitu seni musik al-banjari. Seni musik al-banjari merupakan salah satu seni musik tradisional asli Indonesia, yang dikemas sebaik mungkin yang didalam musik tersebut ada sholawat didalamnya di tambah alunan suara bas, terbang, dan Keplak yang menjadi satu sehingga terbentuklah suatu seni musik yang saat ini dikenal dengan istilah Al-banjari. Perkembangan musik al-banjari, sudah banyak grub-grub banjari bermunculan, karena mengingat al-banjari sangat menghibur, di sisi lain, mereka juga bersholawat kepada Nabi Muhammad SAW. Selain dengan bertambah banyaknya grub banjari yang bermunculan, banyak juga festival sholawat al-banjari pada momen-momen tertentu, seperti yang pernah di selenggarakan oleh UKM UKKI UMAHA yang sudah rutin tiap tahun mengadakan festival tersebut. 
Karena harga alat musik al-banjari yang tergolong agak mahal untuk pelajar, penulis memiliki sebuah gagasan untuk menciptakan sebuah aplikasi "Alat Musik Berbasis Android", aplikasi tersebut bertujuan untuk membuat suatu alat pembelajaran memainkan alat musik al-banjari secara mobile berbasis android, selain itu juga memberikan pengetahuan tentang macam macam alat musik al-banjari, dan cara memainkan alat musik terbsebut. Dengan diciptakannya aplikasi ini memungkinkan pengguna untuk berinteraksi secara langsung dalam proses bermain musik al-banjari sesuai dengan mekasnisme alat musik yang sesungguhnya.

\section{State of the Art}

Pada penelitian kali ini menggunakan metode ADDIE. Model ADDIE terdiri atas lima tahap, yaitu Analisis (Analysis), perancangan (Design), pengembangan (Development), implementasi (Implementation), dan evaluasi (Evaluation) (Muruganantham, 2015)

\section{Method}

Alur penelitian pada aplikasi seni musik al-banajri dapat dilihat pada Gambar 1 .

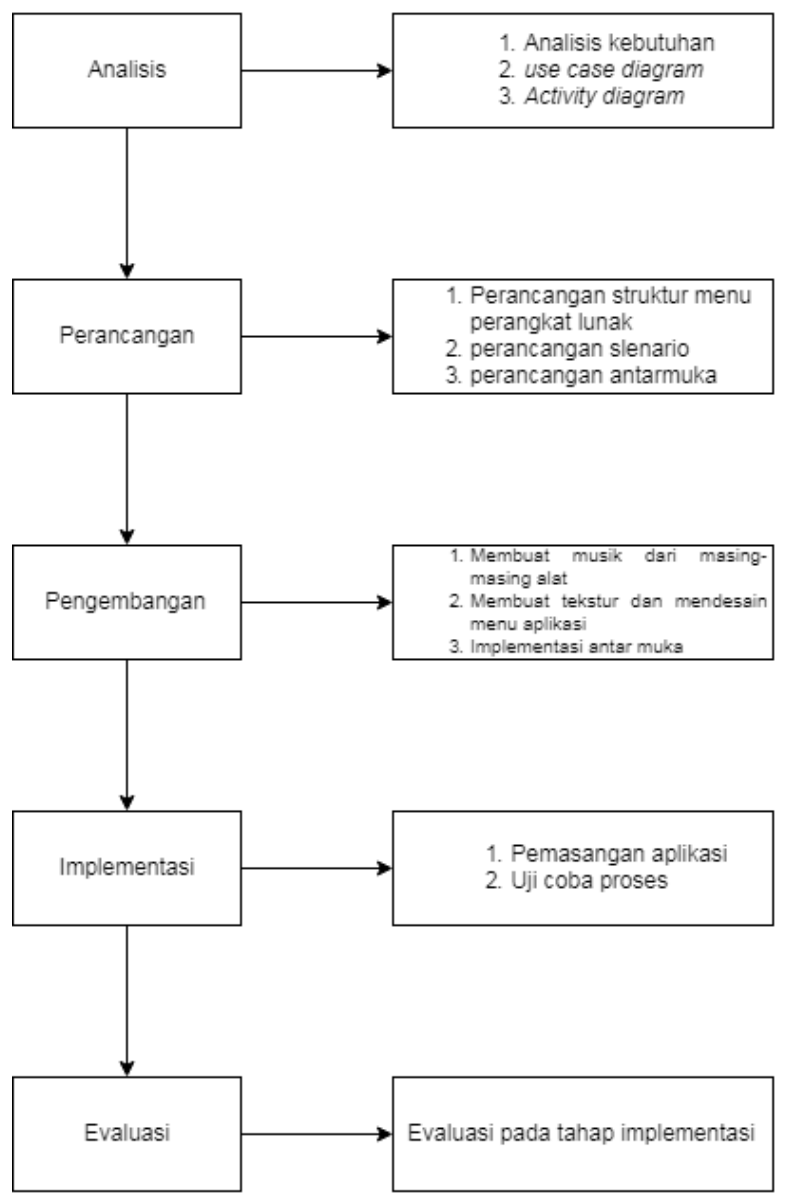

Gambar 1. Tahapan Penelitian Pada Aplikasi Al-Banjari

Tahap pertama adalah tahap analisis, meliputi pengumpulan informasi dan juga kebutuhan secara lengkap, setelah itu informasi tersebut di analisis dan didefinisikan sesuai kebutuhan pada pembuatan aplikasi. Seni musik al-banjari sendiri, memiliki beberapa jenis suara, Pada alat musik terbang, suara dasarnya yaitu : dung, dan tak. Pada bass, suara dasar yaitu : der dan duk. Jika dimainkan dalam ritme atau aturan tertenu maka akan menghasilkan suara yang layak untuk didengar.

Tahap yang kedua adalah tahap desain, meliputi perancangan struktur menu yang tersedia pada aplikasi, berikut gambaran rancangan struktur menu seperti pada gambar 2 . 


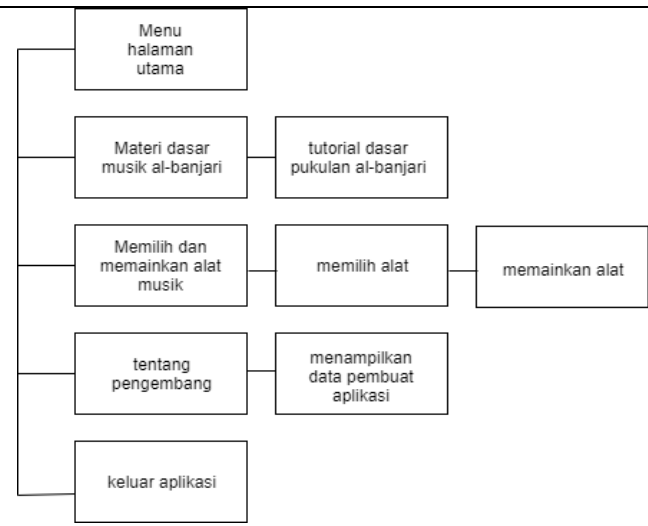

Gambar 2. Rancangan Struktur Menu

Berikut ini adalah penjelasan dari fungsi-fungsi seperti yang terlihat di gambar 2 :

1. Halaman pertama ketika menjalankan aplikasi adalah menu utama, yang di dalamnya terdiri dari empat menu, yakni : materi dasar, memilih dan memainkan alat musik, tentang pengembang, dan keluar aplikasi.

2. Apabila user memilih materi dasar pada menu, user akan menuju ke halaman contoh dasar pada alat musik tersebut, dalam seni musik al-banjari, sering dikenal dengan pukulan lanangan, dan wedokan. Pada menu tersebut menampilkan video contoh pukulan lanangan, wedokan, bass, dan keplak.

3. Apabila user memilih tombol alat musik pada menu, aplikasi menampilkan tiga gambar alat musik yang berbeda, yakni : terbang, Bass, dan keplak. User bisa menekan salah satu gambar alat musik untuk memilih alat musik mana yang akan dimainkan, untuk alat musik terbang, bisa menggunakan satu atau dua alat. setelah itu aplikasi akan menampilkan tampilan alat musik yang ingin dimainkan dan pengguna bisa memainkan alat musik yang sudah di pilih.

4. Apabila user memilih tentang pengembang pada menu, maka aplikasi akan menampilkan data about yang berisi informasi-informasi tentang alat musik al-banjari ke layar pengguna.

5. Apabila user memilih keluar, sistem akan keluar dari aplikasi tersebut.

Dari rancanngan struktur menu tersebut, kemudian di gambarkan masing-maisng Activity diagram dari beberapa fungsi pada rancangan struktur menu.

1. Activity diagram pada menu materi dasar

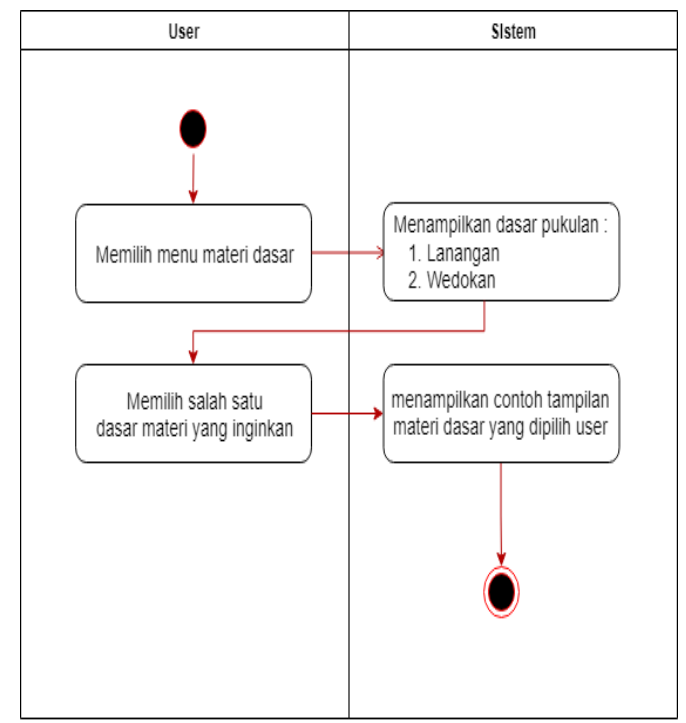

Gambar 3. Activity Diagram Pada Menu Dasar 
Gambar diatas adalah diagram aktivitas antara pengguna dengan sistem untuk melihat materi dasar yang terdapat dalam aplikasi. Pada aktivitas tersebut pengguna bisa melihat materi apa saja yang ada pada sistem dan memilih, kemudian sistem akan menampilkan contoh pukulan dasar musik al-banjari sesuai pilihan user.

2.Activity diagram pada menu pilihan alat musik terbang

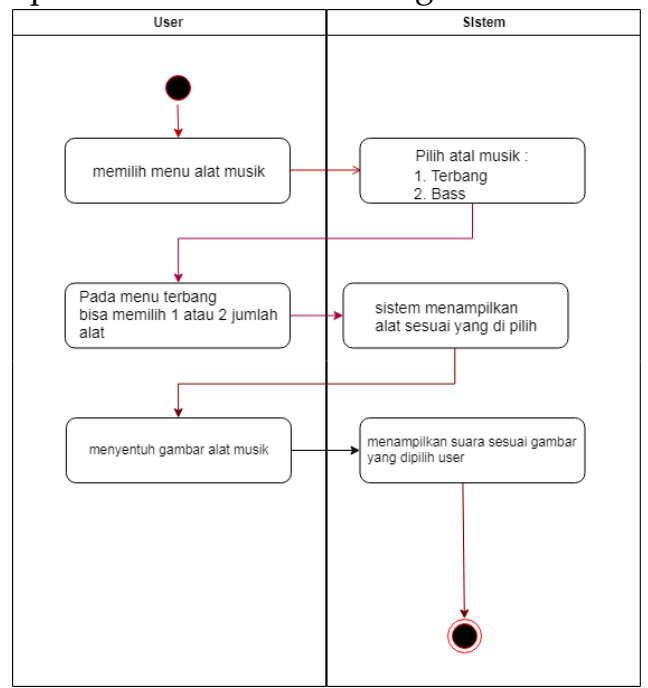

Gambar 4. Activity Diagram Pada Menu Pilihan Alat Musik

Pada gambar tersebut, dijelaskan user diberikan kemudahan oleh aplikasi dalam pemilihan alat musik yang diinginkan, bisa memilih alat terbang, bass, maupun keplak.

3.Activity diagram pada menu tentang pengembang

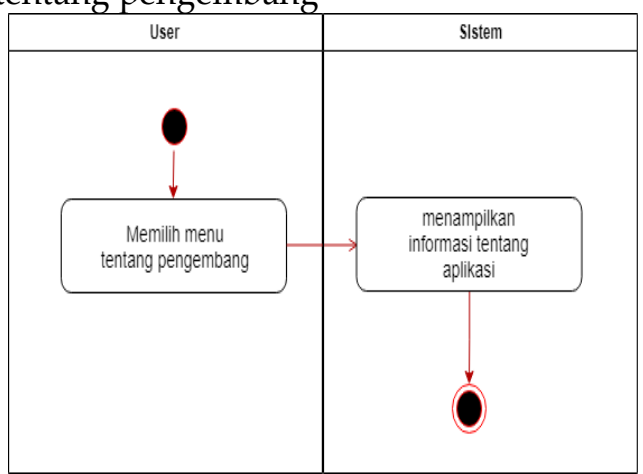

Gambar 4. Activity Diagram Pada Menu Tentang Pengembangan

Pada gambar tersebut, dijelaskan ketika user memilih menu tentang pengembang, maka aplikasi memunculkan tampilan informasi tentang aplikasi.

2. Activity diagram pada menu keluar

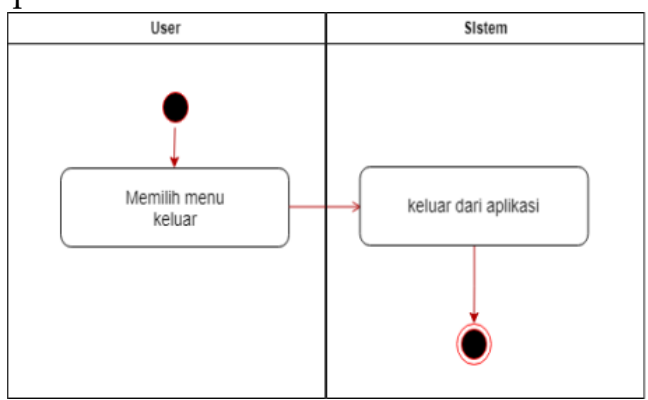

Gambar 4. Activity Diagram Pada Menu Keluar

Pada gambar tersebut, dijelaskan ketika user memilih menu kelaur, maka aplikasi akan tertutup. 
Tahap yang ketiga yaitu tahap pengembangan, tahap ini merupakan lanjutan dari tahap desain, aplikasi tambahan yang di dibutuhkan dalam pengembangan aplikasih musik al-banjari adalah :

1. Grafis, aplikasi yang digunakan untuk mengembangkan adalah Adobe Photoshop untuk membuat tekstur dan mendesain menu aplikasi.

2. Musik dan Suara Efek, aplikasi yang digunakan untuk mengembangkan adalah format factory, untuk memotong beberapa musik.

\section{Hasil and Pembahasan}

\section{Implementasi Sistem}

Aplikasi alat musik al-banjari berbasis android diimplementasikan pada Smartphone Android, dengan menggunakan Tools Android Studio dan JDK Java. Dengan demikian akan diketahui apakah sistem yang sudah dibuat telah berhasil memenuhi tujuan yang di inginkan. Jika Jika sistem sudah berjalan sesuai dengan tujuan, maka sistem tersebut dapat digunakan dikemudian hari, namun jika sistem belum berjalan dengan apa yang diharapkan maka sistem dapat diperbaiki.

\section{Implementasi Program}

Implementasi program yaitu menguji coba aplikasi yang telah dikembangkan. Melalui Smartphone Android. Adapun implementasinya aplikasi harus dijalankan atau di install terlebih dahulu dengan Real Device atau Emulator yang tedapat pada Android Studio, pada smartphone android harus menginstal terlebih dahulu Aplikasi virtual al-banjari.apk. Setelah proses instalasi aplikasi selesai, pengguna bisa membuka aplikasi tersebut, untuk halaman awal aplikasi akan muncul seperti pada gambar 5 .

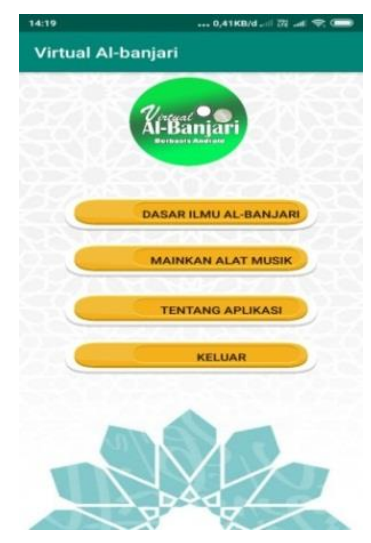

Gambar 4. Menu Awal

Dari gambar nomor 4, terdapat empat menu yaitu : dasar ilmu al-banjari, mainkan alat musik, tentang aplikasi, dan keluar.

\section{a. Menu Dasar}

Pada menu dasar ilmu al-banjari, ketika pengguna memilih menu tersebut, sistem akan menampilkan halaman baru yang berisi video dasar pukulan dasar dari alat musik terbang, bass,dan keplak. Pada alat musik terbang, ada dua jenis pukulan, yaitu lanangan, wedokan, dan juga ada video dari gabungan dari lanangan dan wedokan. 


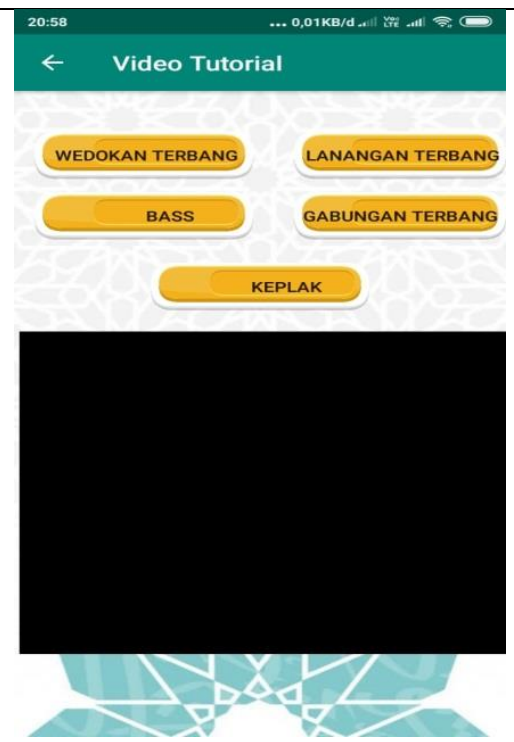

Gambar 5. Tampilan Menu Dasar

Dari gambar 5 terdapat lima button, dan sebuah videoview sebagai pemutar videonya, sistem akan menampilkan video tutorial sesuai dengan pilihan pengguna.

\section{b. Menu Mainkan Alat Musik}

pada menu mainkan alat musik, ketika pengguna memilih menu tersebut, sistem akan menampilkan halaman baru yang berisi tampilan jenis alat musik yang bisa dimainkan pada aplikasi tersebut, yakni alat musik terbang dan bass, agar memudahkan pengguna, icon button tersebut berupa alat musik terbang dan bass. ketika button tersebut di klik, maka sistem akan menampilkan alat musik dan siap di mainkan, pada alat musik terbang, pengguna bisa memilih menggunakan satu alat terbang, atau dua alat terbang. pada alat musik terbang, ketika pengguna menyentuh bagian tengah pada gambar, maka sistem akan mengeluarkan suara dung, ketika pengguna menyentuh bagian samping dari alat musik terbang, maka sistem akan mengeluarkan suara tak. pada alat musik bass, ketika pengguna menyentuh bagian tengah pada gambar, maka sistem akan mengeluarkan suara der, ketika pengguna menyentuh bagian samping dari alat musik bass, maka sistem akan mengeluarkan suara dem.

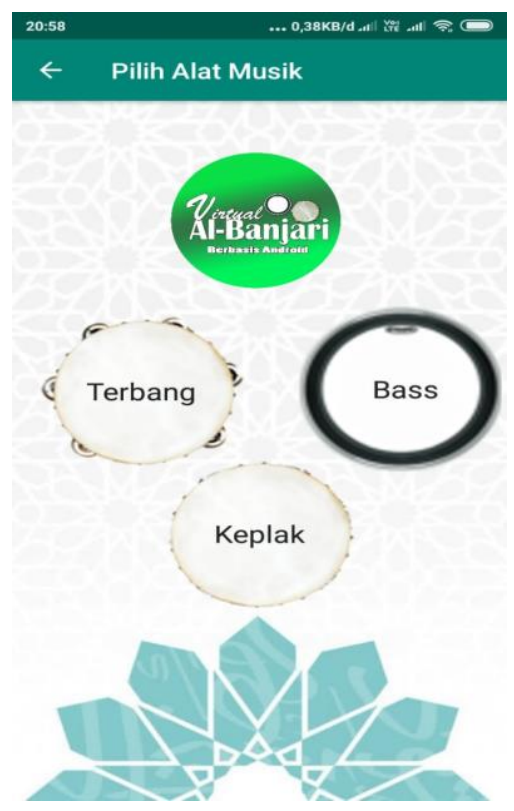


Gambar 5. Tampilan Pilihan Alat Musik

Gambar 5 adalah tampilan dari menu mainkan alat musik, ada dua gambar alat musik dan pengguna bisa memilih salah satu dari kedua alat tersebut.

Apabila pengguna ingin memainkan alat musik terbang, pengguna cukup menyentuh pada gambar terbang. Kemudian sistem memunculkan pesan tentang berapa jumlah terbang yang ingin dimainkan, seperti pada gambar 6 .

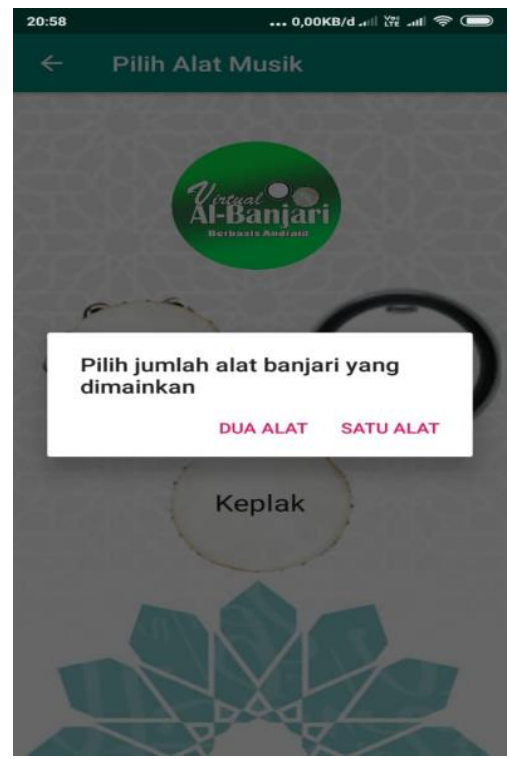

Gambar 6. Tampilah Memilih Jumlah Terbang

ketika pengguna memilih dua alat, sistem akan menampilkan terbang dua alat terbang.

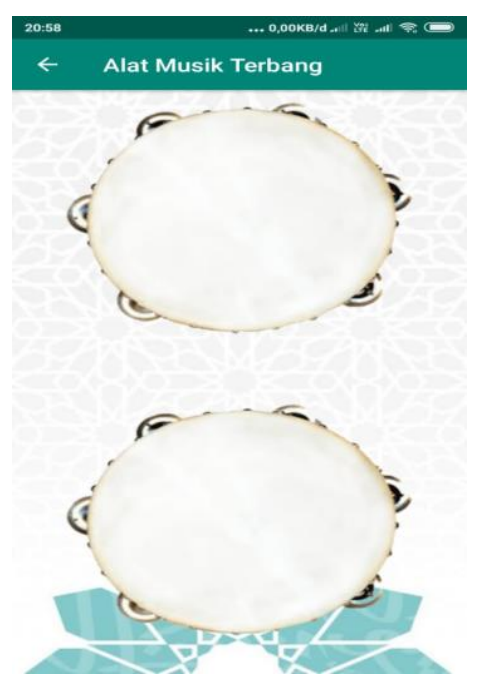

Gambar 7. Tampilah Terbang 2 Alat

Ketika Pengguna Memilih Dua Alat, Sistem Akan Menampilkan Terbang Satu Alat Terbang. 


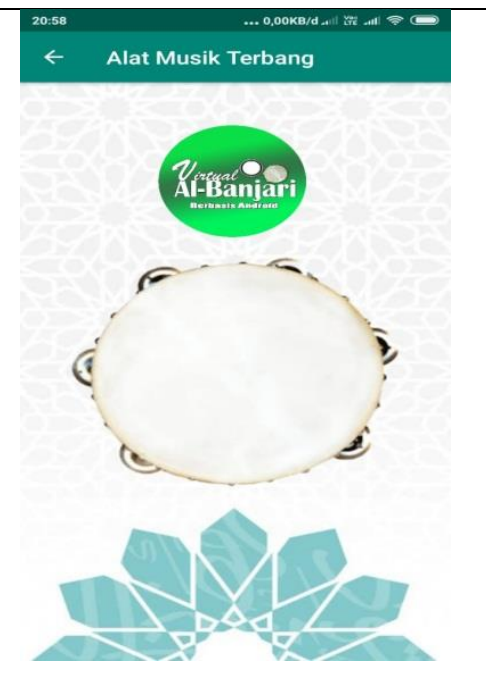

Gambar 8. Tampilah Terbang 1 Alat

Jika pengguna ingin memainkan alat musik bass, pengguna bisa kembali lagi ke menu pilih alat musik seperti pada gambar 5 dengan cara menyentuh tombol kembali yang ada pada tiltle bar, setelah itu pengguna agar bisa masuk pada tampilan alat musik bass, pengguna bisa menyentuh gambar alat musik bass yang ada pada tampilan alat musik.

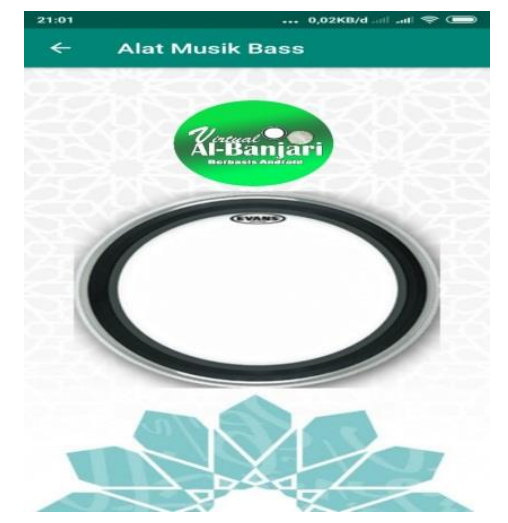

Gambar 9. Tampilah Alat Musik Bass

Jika pengguna ingin memainkan alat musik keplak, pengguna bisa melakukan hal yang sama untuk kembali ke menu pilih alat musik, kemudian pengguna memilih gambar keplak, untuk memainkan alat musik keplak. 


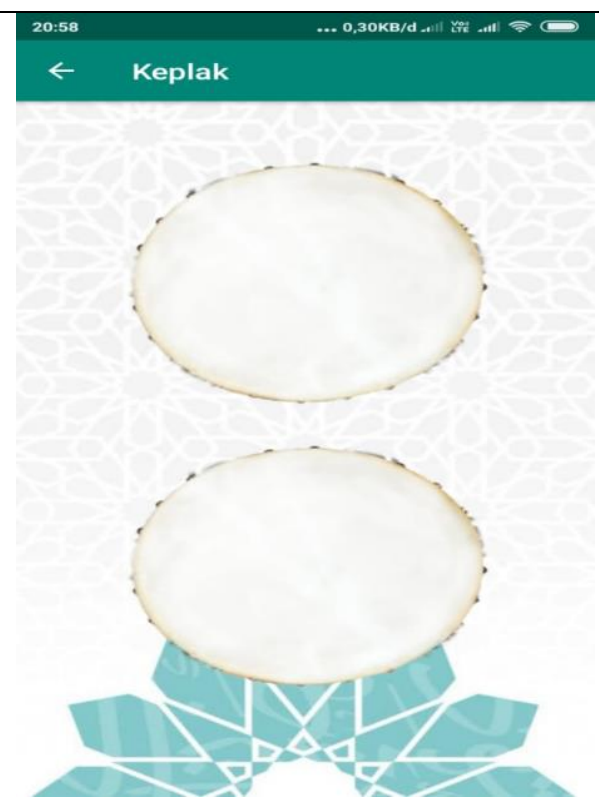

Gambar 10. Tampilah Alat Musik Keplak

c. Menu Tentang Aplikasi

Pada menu mainkan alat musik, ketika pengguna memilih menu tersebut, sistem akan menampilkan halaman baru yang berisi tulisan tentang aplikasi tersebut.

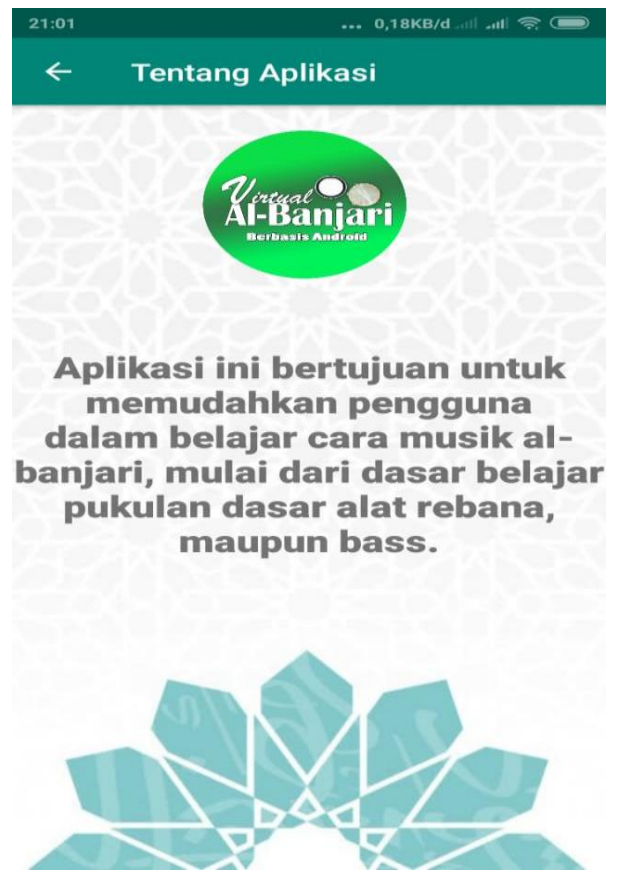

Gambar 11. Tampilan Menu Tentang Aplikasi

\section{d. Menu Keluar}

Ketika pengguna menyentuh button keluar, maka sistem akan menampilkan pesan konfirmasi, jika memilih iya, aplikasi akan berhenti. 


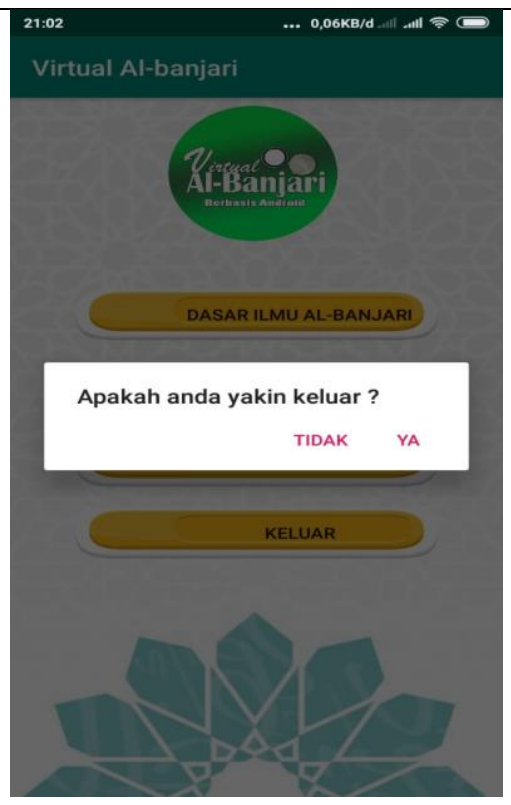

Gambar 12. Tampilan Konfirmasi Menutup Aplikasi

\section{Kesimpulan}

Diharapkan dengan adanya aplikasi ini anggota jamiyah dakwatul ihsan yang ada di dusun Sambiroto Taman, dapat menggunakannya dengan tepat, sebagai media belajar alat musik al-banjari yang dapat di akses menggunakan smartphone. Aplikasi ini menggunakan versi Android 4.3 atau dengan API Level 18. Karena pengguna untuk versi di bawah 4.3 sudah jarang penggunanya, hanya sekitar 1,9\% dari seluruh pengguna Android di dunia.

Bahasa pemrograman yang digunakan dalam pembuatan aplikasi dengan sistem operasi android seperti aplikasi virtual al-banjari adalah java untuk controllernya dan $x m l$ sebagai tampilannya. namun, tidak semua aplikasi android menggunakan java, ada juga yang menggunakan bahasa pemrograman kotlin. maka, penulis menyarankan, jika ada yang ingin membuat aplikasi berbasis android untuk mempelajari bahasa pemrograman kotlin. Keuntungan yang didapat ketika menggunakan kotlin adalah:

1. Aman dari null, tidak perlu khawatir akan timbulnya null pointer exception. compiler folding pada controller java.

2. Anotasi data yang otomatis dibuat untuk mengurangi boilerplate, seperti equals, hashcode, tostring.

3. Syntax sederhana.

Deduksi atau kesimpulan dibuat dari uraian sebelumnya dengan tambahan pendapat pribadi yang argumentatif. Hal ini juga harus mencakup keterbatasan penelitian dalam hal proses, teori yang digunakan, metode yang diterapkan, atau generalisasi hasil yang akan menjadi landasan untuk penelitian lebih lanjut. Bagian ini juga digunakan untuk memberikan gambaran atau rekomendasi untuk penelitian lebih lanjut tentang subjek yang berfungsi sebagai tanggapan terhadap keterbatasan yang diamati. Selain itu, implikasi dari penelitian juga harus dimasukkan.

\section{Refrensi}

[1] Arifianto, T., Nurullah, Q. S., \& Syufagi, M. A. (2018). Perancangan Aplikasi Alat Musik Tradisional Rebana Berbasis Android untuk Pembelajaran Ekstrakurikuler Hadrah di SLB BC Nusantara Bangil Kab. Pasuruan. Rekayasa, 11(2), 146-152.

[2] Developer. (2019). MediaPlayer. Retrieved July 18, 2019, from https://developer.android.com/reference/android/media/MediaPlayer 
[3] Hidayati, K. H., \& Nafiiyah, N. N. (2017). Aplikasi Alat Musik Tradisional Gamelan Jawa Berbasis Android. Jurnal Teknika, 9(1), 10.

[4] Muruganantham, G. (2015). Developing Of E-Content Package By Using ADDIE model. International Journal of Applied Research, 1(3), 52-54.

[5] Purwoko, S. A. (2019). 16 Urutan Versi Android dari Awal Hingga Android Q Terbaru \& Terlengkap 2019. Retrieved March 6, 2019, from https://jalantikus.com/tips/urutan-versi-android/

[6] Rani, C. R., Kumar, A. P., Adarsh, D., Mohan, K. K., \& Kiran, K. V. (2012). Location Based services In Android. International Journal of Advances in Engineering \& Technology, 3(1), 209.

[7] Stackoverflow. (2013a). Android - Back button in the title bar. Retrieved July 13, 2019, from https://stackoverflow.com/questions/14545139/android-back-button-in-the-title-bar

[8] Wikipedia. (2019). Android Studio. Retrieved March 3, 2019, from https://en.wikipedia.org/wiki/Android_Studio

[9] Stackoverflow. (2013b). How to set OnTouchListener For The Entire Screen? Retrieved July 9, 2019, from https://stackoverflow.com/questions/1773835/how-to-set-ontouchlistener-for-the entire-screen

[10] Youtube. (2016). How To Use Image Button With Android Studio To Do Anything. Retrieved July 18, 2019, from https://www.youtube.com/watch?v=VX5nxFwAQ-M 